Florida International University

FIU Digital Commons

FIU Electronic Theses and Dissertations

University Graduate School

$7-25-2000$

\title{
The role of death qualification in venirepersons' evaluations of aggravating and mitigating circumstances in capital trials
}

Brooke M. Butler

Florida International University

DOI: $10.25148 /$ etd.FI14052506

Follow this and additional works at: https://digitalcommons.fiu.edu/etd

Part of the Psychology Commons

\section{Recommended Citation}

Butler, Brooke M., "The role of death qualification in venirepersons' evaluations of aggravating and mitigating circumstances in capital trials" (2000). FIU Electronic Theses and Dissertations. 2001.

https://digitalcommons.fiu.edu/etd/2001

This work is brought to you for free and open access by the University Graduate School at FIU Digital Commons. It has been accepted for inclusion in FIU Electronic Theses and Dissertations by an authorized administrator of FIU Digital Commons. For more information, please contact dcc@fiu.edu. 
Miami, Florida

THE ROLE OF DEATH QUALIFICATION IN VENIREPERSONS' EVALUATIONS

OF AGGRAVATING AND MITIGATING CIRCUMSTANCES

IN CAPITAL TRIALS

A dissertation submitted in partial fulfillment of the

requirements for the degree of

DOCTOR OF PHILOSOPHY

in

PSYCHOLOGY

by

Brooke M. Butler

2000 
To: Dean Arthur W. Herriott

College of Arts and Sciences

This dissertation, written by Brooke M. Butler, and entitled The Role of Death Qualification in Venirepersons' Evaluations of Aggravating and Mitigating

Circumstances in Capital Trials, having been approved in respect to style and intellectual content, is referred to you for judgment.

We have read this dissertation and recommend that it be approved.

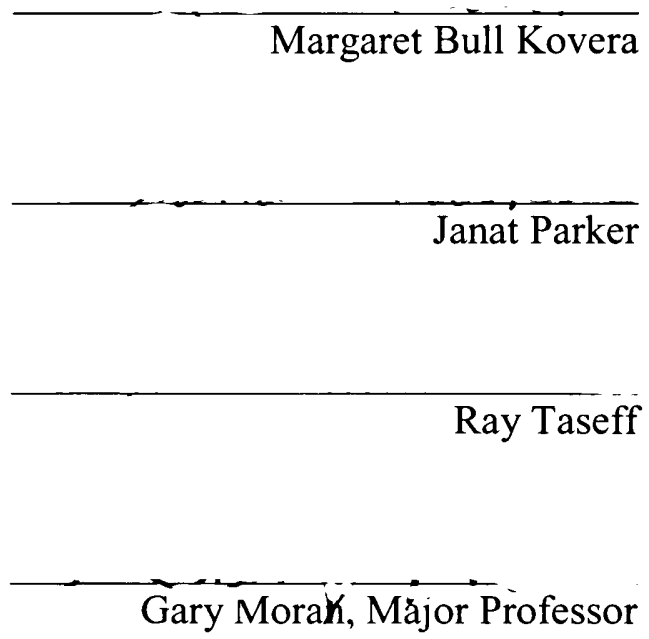

Date of Defense: July 25, 2000

The dissertation of Brooke M. Butler is approved.

Dean Arthur W. Herriott
College of Arts and Sciences

Florida International University, 2000 


\section{DEDICATION}

I dedicate this dissertation to our late Chairperson of the Psychology Department, Scott L. Fraser. 


\section{ACKNOWLEDGMENTS}

First and foremost, I would like to thank my Committee Members, Margaret Bull Kovera, Gary Moran, Janat Parker, and Ray Taseff, for their wisdom and guidance through this rather grueling (albeit exhilarating) process. I would like to extend special appreciation to my Major Professor, Gary Moran, for his brilliance, his friendship, and his uncanny ability to always make me laugh.

I would like to express my sincerest gratitude to my family and friends: my mother, who learned to accept the fact that she raised a daughter who, to her sheer horror, turned out to be a "bleeding-heart liberal," my late father, who taught me that I could do anything I put my mind to; Karen, analyzed my neuroses; Doug, who listened to my neuroses; Adina, who understood my neuroses; Mark, who sympathized with my neuroses; and Cachi and Marie, who made me laugh at my neuroses.

I would like to thank Anders Madsen, the Director of the Jury Pool at the Eleventh Judicial Circuit of the State of Florida, for graciously allowing me to collect my data from bored venirepersons who just wanted to go home. I would also like to extend my appreciation to the secretaries of the Psychology Department, Annette, Carmen, and Luz, for helping me in any way they could (which usually meant looking the other way when their "bruja loquita" exceeded the maximum number of copies she was allowed to make on the copy card).

Last but not least, I would like to extend my deepest gratitude to our late Chairperson of the Psychology Department, Scott Fraser, who taught me statistics, unconditional kindness, and that life is much, much too short not to have a good time. Now, I'm off to Greece... 


\title{
ABSTRACT OF THE DISSERTATION
}

\section{THE ROLE OF DEATH QUALIFICATION IN VENIREPERSONS' EVALUATIONS}

\author{
OF AGGRAVATING AND MITIGATING CIRCUMSTANCES \\ IN CAPITAL TRIALS \\ by \\ Brooke M. Butler \\ Florida International University, 2000 \\ Miami, Florida \\ Professor Gary Moran, Major Professor
}

Death qualification is a part of voir dire that is unique to capital trials. Unlike all other litigation, capital jurors must affirm their willingness to impose both legal standards (either life in prison or the death penalty). Jurors who assert they are able to do so are deemed "death-qualified" and are eligible for capital jury service; jurors who assert that they are unable to do so are deemed "excludable" or "scrupled" and are barred from hearing a death penalty case. During the penalty phase in capital trials, death-qualified jurors weigh the aggravators (i.e., arguments for death) against the mitigators (i.e., arguments for life) in order to determine the sentence. If the aggravating circumstances outweigh the mitigating circumstances, then the jury is to recommend death; if the mitigating circumstances outweigh the aggravating circumstances, then the jury is to recommend life. The jury is free to weigh each aggravating and mitigating circumstance 
in any matter they see fit. Previous research has found that death qualification impacts jurors' receptiveness to aggravating and mitigating circumstances (e.g., Luginbuhl \& Middendorf, 1988). However, these studies utilized the now-defunct Witherspoon rule and did not include a case scenario for participants to reference. The purpose of this study was to investigate whether death qualification affects jurors' endorsements of aggravating and mitigating circumstances when $\underline{\text { Witt, }}$ rather than Witherspoon, is the legal standard for death qualification. Four hundred and fifty venirepersons from the $11^{\text {th }}$ Judicial Circuit in Miami, Florida completed a booklet of stimulus materials that contained the following: two death qualification questions; a case scenario that included a summary of the guilt and penalty phases of a capital case; a 26-item measure that required participants to endorse aggravators, nonstatutory mitigators, and statutory mitigators on a 6-point Likert scale; and standard demographic questions. Results indicated that death-qualified venirepersons, when compared to excludables, were more likely to endorse aggravating circumstances. Excludable participants, when compared to death-qualified venirepersons, were more likely to endorse nonstatutory mitigators. There was no significant difference between death-qualified and excludable venirepersons with respect to their endorsement of 6 out of 7 statutory mitigators. It would appear that the Furman v. Georgia (1972) decision to declare the death penalty unconstitutional is frustrated by the Lockhart v. McCree (1986) affirmation of death qualification. 
I. LITERATURE REVIEW.

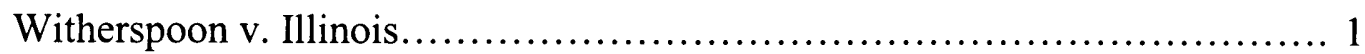

Wainwright $v$. Witt................................................... 3

Lockhart v. McCree....................................................... 5

Lockett v. Ohio.......................................................... 6

Hypotheses.........................................................

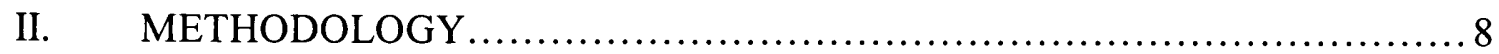

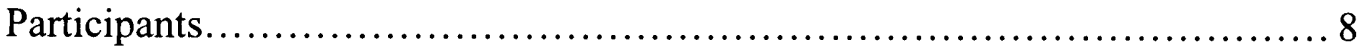

Stimulus Case ........................................................ 9

Predictor Variable ........................................................ 10

Dependent Measure...................................................... 10

Procedure................................................................. 11

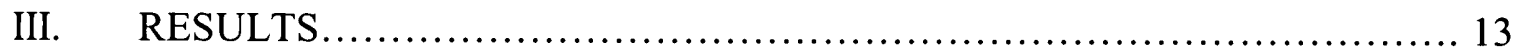

Aggravating Circumstances................................................13

Statutory Mitigating Circumstances...................................... 15

Nonstatutory Mitigating Circumstances................................. 15

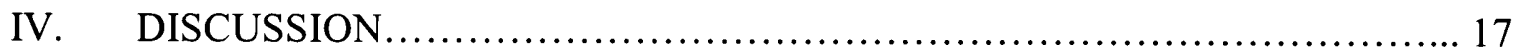

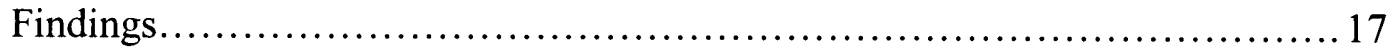

Legal Implications ................................................ 20

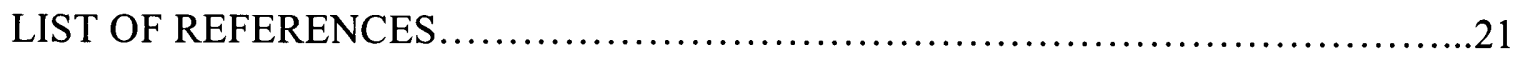

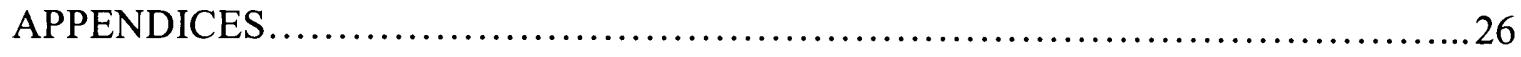

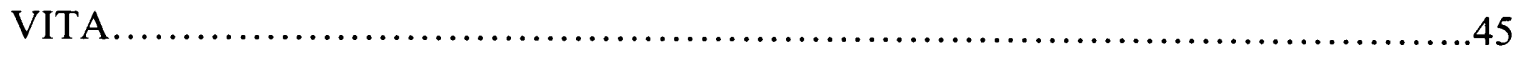




\section{CHAPTER I}

\section{LITERATURE REVIEW}

In the United States, the jury has a central role in capital (or death penalty) trials. In all but a few states that retain capital punishment, the jury has the primary responsibility of pronouncing either a death or life sentence. This obligation is extremely unusual, considering the fact that it is not constitutionally mandated and jury sentencing in non-capital trials is almost extinct (Hans, 1986). A primary difference between capital jurors and jurors in other cases is that death penalty jurors must undergo an extremely controversial process called death qualification.

Death qualification is a part of voir dire that is unique to capital trials. During death qualification, prospective jurors are questioned regarding their beliefs about capital punishment. This process serves to eliminate jurors whose attitudes toward the death penalty would render them unable to be fair and impartial in deciding the fate of a defendant. In order to sit on a capital jury, a person must be willing to consider all legal penalties as appropriate forms of punishment. Jurors who "pass" the aforementioned standard are deemed "death-qualified" and are eligible for capital jury service; jurors who "fail" the aforementioned standard are deemed "excludable" or "scrupled" and are barred from hearing a death penalty case.

Two United States Supreme Court cases are pivotal in the standards for deathqualified and excludable jurors. In Witherspoon v. Illinois (1968), the Court ruled that death qualification could exclude

...only those potential jurors who made unmistakably clear (1) that they would automatically vote against the imposition of capital punishment without regard to 
any evidence that might be developed at the trial before them, or (2) that their attitude toward the death penalty would prevent them from making an impartial decision as to the defendant's guilt (p. 522).

For almost twenty years, the Witherspoon standard was the only standard for death qualification. However, several studies found that this standard is problematic in its violation of a defendant's right to both due process and a jury of one's peers. For example, Fitzgerald and Ellsworth (1984) found that, under Witherspoon, significantly greater numbers of Blacks and women would be excluded from sitting on capital juries. In addition, death-qualified jurors, when compared to their excludable counterparts, were more likely to favor the arguments made by the prosecution, mistrust defendants and defense attorneys, endorse a punitive approach toward offenders, place more importance on crime control than due process, and express less regret concerning erroneous convictions and more regret concerning erroneous acquittals (Fitzgerald \& Ellsworth, 1984; Thompson, Cowan, Ellsworth, \& Harrington, 1984).

In addition, Robinson (1993) found that only $40 \%$ of Witherspoon excludables refused to consider the death penalty in all cases, with the remaining $60 \%$ indicating that they would consider the death penalty in some cases. The author argued that the majority of jurors being excluded from capital juries under the Witherspoon standard would impose the death penalty for capital crimes.

Perhaps more importantly, the aforementioned attitudes translate into behavior. Zeisel (1968), Cowan, Thompson, and Ellsworth (1984), and Moran and Comfort (1986) found that, when compared to Witherspoon excludables, pro-death-penalty persons were 
significantly more willing to convict in both mock and real trials. This effect occurred on initial ballots as well as after deliberation.

A major change in the standard for death qualification occurred in Wainwright $\mathrm{v}$. Witt (1985). According to this ruling, in the opinion of the judge, if a potential juror feels so strongly about the death penalty that [his/her] belief would "prevent or substantially impair the performance of his duties as a juror, it is grounds for dismissal for cause" (p. 852).

Although the Court sought to enhance the fairness and impartiality of capital juries by utilizing the Witt standard, the data indicate that this modification did not have the intended effect. Research has indicated that adoption of the Witt standard has significant consequences. In fact, Dillehay and Sandys (1996) found that $28 \%$ of jurors who met the Witt standard would, contrary to law, automatically impose the death penalty. Thirty-six percent of all jurors showed inconsistencies with the Witt criterion, meaning their attitude toward the death penalty was so vehement that it prevented them from being impartial in a capital case. In addition, Neises and Dillehay (1987) have found that Witt has excluded significantly more potential jurors (21\%) than Witherspoon (14\%), which has resulted in juries that are even less representative.

Opposition to the death penalty, however defined, is more frequent in certain demographic and attitudinal subgroups than others. For example, significant numbers of women, Jews, Blacks, agnostics, atheists, Democrats, and people with a low socioeconomic status are excluded from capital jury service (Hans, 1986; Moran \& Comfort, 1986). 
In fact, jurors who pass the Witt standard tend to be demographically distinguishable: They are more likely to be male, White, financially secure, Republican, and Catholic or Protestant (Hans, 1986). Also, when compared to excludable jurors, death-qualified jurors, among other things, are more likely to ...trust prosecutors and distrust defense attorneys, consider inadmissible evidence even if a judge instructed them to ignore it, and infer guilt from a defendant's [failure to take the witness stand]. Death-qualified jurors are more hostile to psychological defenses such as schizophrenia. They tend to view prosecution witnesses as more believable, more credible, and more helpful. They are less likely to believe in the fallibility of the criminal justice process, and less likely to agree that even the worst criminals should be considered for mercy (Hans, 1986, p. 152).

Capital trials are bifurcated; they consist of a guilt phase and a penalty phase. Haney (1984) argues that the experience of death qualification itself affects jurors' perceptions of both parts of a death penalty case. Capital voir dire is the only voir dire that requires the penalty to be discussed before it is relevant. Thus, the focus of jurors' attention is drawn away from the presumption of innocence and onto postconviction events. The time and energy spent by the court presents an implication of guilt and suggests to jurors that the penalty is relevant, if not inevitable (Haney, Hurtado, \& Vega, 1994).

Death qualification also forces jurors to imagine themselves in the penalty-phase proceeding. Previous research has found that simply assuming an event will occur increases the subjective estimate that it will (Tversky \& Kahneman, 1974). During death 
qualification, jurors are questioned repeatedly about their views on the death penalty.

This can have two negative byproducts. Jurors can become desensitized to the imposition of the death penalty due to repeated exposure to this potentially emotional issue. Also, jurors are forced to publicly commit to a particular viewpoint. Earlier findings have suggested that public affirmation of an opinion can actually cause that opinion to strengthen (Festinger, 1957). Jurors who do not endorse the death penalty also encounter implied legal disapproval by being judged "unfit for service."

A final United States Supreme Court case is critical in the discussion of death qualification. In Lockhart v. McCree (1986), the American Psychological Association submitted an amicus curiae brief to the Court summarizing the findings of a body of research on death qualification. In this brief, the APA argued the following points: (1) death-qualified juries are conviction-prone; (2) barring Witherspoon excludables creates juries that are unrepresentative, which impairs a defendant's right to a jury of his peers; and (3) death qualification impairs the proper functioning of a jury (Bersoff, 1987). This brief summarized two decades of post Witherspoon research. The APA posited that the data demonstrate that death-qualified juries are more pro-prosecution, pro-conviction, and less representative than juries that are not death-qualified and that death qualification should be abolished (Bersoff, 1987).

The Supreme Court reviewed the research and criticized the studies presented by the APA as having "serious flaws in the evidence upon which the courts below had concluded that 'death qualification' produces 'conviction-prone' juries”' (Lockhart v. McCree, 1986, p. 1764). In conclusion, the Court ignored the weight of the data, the implications of convergent validity, and declared the data submitted by the APA 
inadequate and legally irrelevant, thereby ruling the process of death qualification constitutional (Thompson, 1989). Although death qualification appears to be moot in law, it is not settled fact. Additional research is warranted concerning the fairness of death qualification.

One such area of research is jurors' perceptions of aggravating and mitigating circumstances. In most states that have capital punishment, the jury is primarily responsible for the sentence. If a conviction occurs in a capital case, the jury then determines the penalty by weighing the mitigating circumstances (i.e., arguments for life) against the aggravating circumstances (i.e., arguments for death). If the aggravators outweigh the mitigators, the jury is to recommend the death sentence; if the mitigators outweigh the aggravators, then the jury is to recommend life in prison. In Florida, the judge has the ultimate opinion in capital cases. However, the recommendation of the jury is rarely overturned (Luginbuhl \& Middendorf, 1988).

The Supreme Court has ruled in Lockett v. Ohio (1978) that aggravating circumstances are limited by statute; mitigating circumstances are not (see Appendix A). In Florida, there are $14 \underline{\text { specific }}$ aggravating circumstances; the judge has the final opinion on which, if any, of the 14 the jury may consider. Examples aggravators include, "The crime for which the defendant is to be sentenced was committed for the purpose of avoiding or preventing a lawful arrest or effecting an escape from custody," and "The defendant, in committing the crime for which [he] [she] is to be sentenced, knowingly created a great risk of death to many persons."

In contrast, there are eight examples of mitigating circumstances. Examples of mitigators include, "(Defendant) has no significant history of prior criminal activity," and 
"The victim was a participant in the defendant's conduct or consented to the act." Although the judge also has the final word on which, if any, will be considered, mitigating circumstances are merely suggestions. In fact, the jury may consider "Any other aspect of the defendant's character, record, or background" as well as "Any other circumstance of the offense."

Previous research has found that excludable jurors are more receptive to mitigating than aggravating circumstances (Luginbuhl \& Middendorf, 1988). However, this study utilized the now-defunct Witherspoon rule. It is imperative to investigate whether death qualification affects jurors' endorsements of special circumstances when they are categorized under the current $\underline{\text { Witt standard. }}$

In addition, earlier studies have asked jurors to classify a list of special circumstances as either aggravators or mitigators without including a stimulus case vignette. Earlier research has suggested that hearing a case sensitizes jurors to their preexisting attitudes (Hans, 1986). In addition, real jurors have to hear the evidence in a case before deciding the fate of a defendant; participant jurors should have this point of reference as well.

The primary purpose of the current study is to investigate the differences between death-qualified and excludable jurors' evaluations of aggravating and mitigating circumstances. Based on the findings of similar studies, it is hypothesized that deathqualified jurors, when compared to Witt excludables, will be more likely to endorse aggravating circumstances. It is also predicted that excludables, as opposed to deathqualified jurors, will be more likely to endorse both nonstatutory and statutory mitigating circumstances. 


\section{CHAPTER II}

\section{METHODOLOGY}

\section{$\underline{\text { Participants }}$}

Participants consisted of 450 venirepersons who had been called for jury duty at the Eleventh Judicial Circuit in Miami, Florida. Fifty-nine percent of participants were women; $41 \%$ were men.

Twenty percent were between the ages of 18 to $24 ; 21 \%$ were between the ages of 25 to $34 ; 20 \%$ were between the ages of 35 to $44 ; 22 \%$ were between the ages of 45 to $54 ; 12 \%$ were between the ages of 55 to 64 ; and $4 \%$ were 65 and older. The ethnic background of the sample was as follows: $32 \%$ were White/Non-Hispanic; $51 \%$ were White/Hispanic; $2 \%$ were Black/Hispanic; $10 \%$ were Black; and $5 \%$ were of a race other than what was specified on the questionnaire.

One percent of respondents had no high school education; $4 \%$ had some high school; $14 \%$ had completed high school; $40 \%$ had some college or junior college; $27 \%$ had a college degree; and $15 \%$ had a post-graduate or professional degree. Twenty-seven percent of the jurors had served on a jury before.

Ten percent reported that their annual family income was less than $\$ 20,000 ; 16 \%$ were between $\$ 20,000$ and $\$ 30,000 ; 19 \%$ were between $\$ 30,000$ and $\$ 45,000 ; 21 \%$ were between $\$ 45,000$ and $\$ 60,000 ; 9 \%$ were between $\$ 60,000$ and $\$ 75,000$; and $24 \%$ of participants said their annual family income was $\$ 75,000$ or more. One percent of venirepersons did not answer the aforementioned question. 


\section{$\underline{\text { Stimulus Case }}$}

First, venirepersons read the summary of testimony presented during the guilt phase of a capital trial involving the robbery and murder of a convenience store clerk (see Appendix B). Three eyewitnesses saw a man enter the convenience store and demand money from the cashier. When the cashier turned around to open the register, the perpetrator shouted at him to "hurry up." The cashier fumbled with the register, and the perpetrator shot him once, killing him instantly. The perpetrator then took the money out of the register (amounting to $\$ 300$ ) and fled. A short time later, the police found a man who matched the description of the murderer walking near the convenience store. The man, Andrew Jones, did not have an alibi for his whereabouts at the time of the crime. They searched him and found $\$ 300$. The police arrested Mr. Jones and took him to the police station. In a subsequent lineup, the three eyewitnesses positively identified $\mathrm{Mr}$. Jones as the person they had seen kill the convenience store clerk. His fingerprints were also found at the scene of the crime.

Second, venirepersons then read the summary of arguments and testimony presented during the penalty phase of the aforementioned capital trial (see Appendix B). The prosecution presented the following aggravating circumstances and urged participants to vote in favor of the death penalty: the murder occurred during the commission of another felony; the defendant has a prior history of violence; the crime was committed while Mr. Jones was on probation; the crime was committed in order to avoid identification and arrest; the victim was murdered for $\$ 300$; and the crime was committed in a cold, calculated, and premeditated manner. 
The defense attorney presented the following mitigating circumstances and urged venirepersons to sentence the defendant to life in prison without the possibility of parole: Andrew Jones was physically abused as a child; Andrew Jones had served in the military; he has a history of alcoholism and using illegal drugs; he was under the influence of extreme mental or emotional disturbance; and Mr. Jones was taking two types of antidepressants when the murder occurred.

\section{Predictor Variables}

First, venirepersons' specified their level of support for the death penalty. This was assessed in two ways (see Appendix B). First, participants were asked to circle the statement that they agreed with most: (1) The death penalty is never an appropriate punishment for the crime of first-degree murder; (2) In principle, I am opposed to the death penalty, but I would consider it under certain circumstances; (3) In principle, I favor the death penalty, but I would not consider it under all circumstances; and (4) The only appropriate punishment for the crime of first-degree murder is the death penalty.

Second, venirepersons were asked to indicate if they felt so strongly about the death penalty (either for or against it) that their views would prevent or substantially impair the performance of their duties as a juror in a capital case. Participants who answered "No" to the aforementioned question were classified as death-qualified according to Witt; those who answered "Yes" were classified as excludable.

\section{Dependent Measure}

Florida Statute 921.141(5) specifies 14 aggravating factors and Florida Statute 921.141(6) suggests eight mitigating factors that a jury can consider when deciding to sentence a defendant to either death or life in prison without the possibility of parole (see 
Appendix A). Aggravators are legal justifications for the imposition of the death penalty; mitigators are legal justifications for a life sentence. If the jury finds that aggravating circumstances do exist, they then determine whether mitigating circumstances exist that outweigh the aggravating circumstances.

Aggravators are limited by statute; mitigators are not. Examples of items that represent aggravating factors include, "A person who commits murder for the purpose of avoiding or preventing a lawful arrest or effecting an escape from custody should get a more severe punishment," and "If a person, upon committing a crime, knowingly created a great risk of death to many persons, then he should be punished more severely." Examples of items that represent mitigating factors include, "If a person has a history of alcoholism, then they should not be punished severely," and "If the victim was a participant in or consented to the act, then the defendant should be given a lighter sentence."

Twenty-six items were constructed: 14 represented aggravating factors; 12 represented mitigating factors (see Appendix B). Some special circumstances were relevant to the case; others were not. Venirepersons were asked to read each item and indicate their opinion on a 6-point Likert scale, ranging from strong disagreement to strong agreement.

Procedure

Permission to collect data at the courthouse was obtained from the Director of the Jury Pool, Anders Madsen, under the assumption he had the opportunity to review the proposal before the research was undertaken. After the proposal was approved, the experimenter solicited volunteers from an area designated for prospective venirepersons 
who were waiting to be called randomly and assigned to particular cases. Participation was high; the actual response rate was $100 \%$. The unusually high response rate was due to the fact that venirepersons were led to believe their response was requested by the Court. After this brief explanation, everyone in the room was given a survey. All venirepersons who received a booklet completed all questions in their entirety.

Prior to their participation, venirepersons read an informed consent form, which described the nature of the study, ensured that their participation was completely voluntary and anonymous, and reiterated that they would not receive compensation for their participation. Venirepersons were also given a contact number in case they were interested in the final results of the study once the data were collected and analyzed (see Appendix B).

Participants were then asked to complete a booklet of measures. Venirepersons were first asked to complete two death qualification questions. Participants then read a summary of the guilt and penalty phases of a capital case. They were told that the defendant has already been convicted of capital murder; they are responsible for determining the punishment. Venirepersons were then asked to evaluate a list of special circumstances, select a sentence (either death or life in prison without the possibility of parole), and answer standard demographic questions. 


\section{CHAPTER III}

\section{RESULTS}

Venirepersons were normally distributed across the four categories of death penalty attitudes. Thirteen percent $(\underline{n}=57)$ felt the death penalty is never an appropriate punishment for the crime of first-degree murder; $33 \%(\underline{n}=148)$ opposed the death penalty, but would consider it under certain circumstances; $37 \%(\underline{n}=167)$ favored the death penalty in principle, but would not consider it under all circumstances; and $17 \%$ ( $\underline{\mathrm{n}}$ $=78$ ) said the only appropriate punishment for the crime of first-degree murder is the death penalty. Twenty percent $(\underline{n}=90)$ of participants felt so strongly about the death penalty that they said their views would prevent or substantially impair the performance of their duties as a juror in a capital case. These venirepersons were classified as Witt excludables.

The distribution of sentence showed no evidence of ceiling or floor effects. Forty percent $(\underline{n}=178)$ of venirepersons recommended the death penalty; $60 \%(\underline{n}=270)$ suggested a sentence of life in prison without the possibility of parole. Twenty-one percent $(\underline{n}=19)$ of excludables elected to sentence the defendant to death, whereas $79 \%$ $(\underline{n}=71)$ of excludables voted to sentence the defendant to life in prison without the possibility of parole.

Aggravating and mitigating circumstances were divided into three groups: aggravators; nonstatutory mitigators; and statutory mitigators. Because aggravators were correlated with one another ( $\underline{\text { 's }}$ ranged from .40 to $.81, \underline{\mathrm{M}}=.61$ ); nonstatutory mitigators were correlated with one another ( $\underline{\mathrm{r} \text { 's }}$ ranged from .33 to $.57, \underline{\mathrm{M}}=.42$ ); and statutory 
mitigators were correlated with one another ( $\underline{\mathrm{r} \text { 's }}$ ranged from .00 to $.49, \underline{\mathrm{M}}=.15$ ), multivariate analyses of variance (MANOVAs) were performed.

A MANOVA revealed a significant effect of death qualification on evaluations of aggravating circumstances $\left(\underline{\mathrm{F}}(14,430)=10.58, \underline{\mathrm{p}}<.001, \eta^{2}=.26\right)($ see Table 1$)$. Univariate tests demonstrated death-qualified venirepersons, as opposed to excludables, exhibited higher endorsement of all 14 aggravators: the crime is especially heinous, atrocious, or cruel $\left(\underline{\mathrm{F}}(1,443)=98.53, \underline{\mathrm{p}}<.001, \eta^{2}=.18\right)$; a person committed a murder while engaged in the commission of a robbery (or any other crime) $(\underline{F}(1,443)=85.96, \underline{p}$ $<.001, \eta^{2}=.16$ ); a person commits murder for the purpose of avoiding or preventing a lawful arrest or effecting an escape from custody $\left(\underline{\mathrm{F}}(1,443)=80.37, \underline{\mathrm{p}}<.001, \eta^{2}=.15\right)$; a person is a member of a gang $\left(\underline{\mathrm{F}}(1,443)=60.45, \mathrm{p}<.001, \eta^{2}=.12\right)$; the victim was an elderly person or disabled person $\left(\underline{\mathrm{F}}(1,443)=74.19, \underline{\mathrm{p}}<.001, \eta^{2}=.14\right)$; a person murders someone for financial gain $\left(\underline{F}(1,443)=62.53, \underline{p}<.001, \eta^{2}=.12\right)$; a person commits a crime in a cold, calculated, and premeditated manner without any pretense of moral or legal justification $\left(\underline{\mathrm{F}}(1,443)=119.39, \underline{\mathrm{p}}<.001, \eta^{2}=.21\right)$; the victim was a person less than 12 years of age $\left(\underline{F}(1,443)=35.28, \underline{p}<.001, \eta^{2}=.07\right)$; the victim was a law enforcement officer engaged in the performance of the officer's actual duties $(\underline{F}(1$, $\left.443)=70.78, \underline{p}<.001, \eta^{2}=.14\right) ;$ a person commits a crime against an elected or appointed public official engaged in the commission of his official duties $(\underline{F}(1,443)=$ $52.41, \underline{p}<.001, \eta^{2}=.11$ ); a person commits another crime while on felony probation $\left(\underline{\mathrm{F}}(1,443)=17.46, \underline{\mathrm{p}}<.001, \eta^{2}=.04\right) ;$ a person commits a crime to disrupt or hinder the lawful exercise of any governmental function or the enforcement of laws $(\underline{F}(1,443)=$ 
$39.97, \underline{p}<.001, \eta^{2}=.08$ ); a person had been previously convicted of a violent felony $\left(\underline{F}(1,443)=27.72, \underline{p}<.001, \eta^{2}=.06\right) ;$ and a person, upon committing a crime, knowingly caused great risk of death to many persons $\left(\underline{F}(1,443)=42.34, \underline{p}<.001, \eta^{2}=\right.$ $.09)$.

A MANOVA revealed a significant effect of death qualification on evaluations of nonstatutory mitigating circumstances $\left(\underline{F}(5,443)=11.71, \underline{p}<.001, \eta^{2}=.12\right)$ (see Table 2). Univariate tests demorlstrated excludables, as opposed to death-qualified venirepersons, were more likely to endorse all five nonstatutory mitigators: a person has a history of alcoholism $\left(\underline{\mathrm{F}}(1,447)=28.05, \underline{\mathrm{p}}<.001, \eta^{2}=.06\right)$; a person has been impaired by illegal drugs in the past $\left(\underline{F}(1,447)=32.77, \underline{p}<.001, \eta^{2}=.07\right)$; physical abuse as a child $\left(\underline{\mathrm{F}}(1,447)=21.34, \underline{\mathrm{p}}<.001, \eta^{2}=.05\right)$; a person had served in the military before the crime was committed $\left(\underline{F}(1,447)=38.86, \underline{p}<.001, \eta^{2}=.08\right)$; and a person was taking prescription drugs that have the potential to alter their psychological state $(\underline{F}(1,447)=$ $\left.22.69, \mathrm{p}<.001, \eta^{2}=.05\right)$.

A MANOVA showed that death qualification was significantly related to evaluations of statutory mitigating circumstances $\left(\underline{F}(7,436)=2.68, \underline{p}=.01, \eta^{2}=.04\right)$ (see Table 3). Univariate tests demonstrated excludables, as opposed to death-qualified venirepersons, were significantly more likely to endorse only one of the seven statutory mitigators: the defendant was suffering from an extreme mental or emotional disturbance $\left(\underline{\mathrm{F}}(1,442)=12.63, \underline{\mathrm{p}}<.001, \eta^{2}=.03\right)$.

None of the demographic items proved to be significant with respect to death qualification or evaluation of special circumstances. Chi-squares showed no significant 
relationship between death qualification and such characteristics as gender $\left(\chi^{2}(1)=1.99\right.$, $\mathrm{p}=.12)$ and $\operatorname{race}\left(\chi^{2}(4)=5.14, \underline{p}=.27\right)$.

A chi-square did, however, reveal a significant effect of death qualification on sentence $\left(\chi^{2}(1)=16.31, \underline{p}<.001\right)$. Death-qualified venirepersons, as opposed to excludables, were more likely to sentence the defendant to death. Another chi-square showed a significant effect of gender on sentence $\left(\chi^{2}(1)=16.13, \underline{p}<.001\right)$. Men were more likely than women to sentence the defendant to death. 


\section{CHAPTER IV}

\section{DISCUSSION}

This study clearly demonstrates a relationship between death qualification under Witt and evaluations of aggravating and mitigating circumstances. As hypothesized, death-qualified participants, when compared to excludables, were more likely to endorse aggravators. Also as predicted, excludables, as opposed to death-qualified venirepersons, were more likely to endorse nonstatutory mitigators.

One surprising finding is that death qualification had minimal impact on participants' evaluations of statutory mitigators. Excludables, when compared to deathqualified venirepersons, were more likely to endorse only one statutory mitigating circumstance: the defendant was suffering from an extreme mental or emotional disturbance. This may be due to the fact that this statutory mitigator appeared to differ from the others because it implies the presence of psychopathy. Previous research has found death-qualified jurors are less receptive to psychological defenses such as schizophrenia (Hans, 1986). In addition, all venirepersons, regardless of death qualification, may have considered most of the statutory mitigators to be legitimate reasons for sentencing someone to life in prison without the possibility of parole as opposed to the death penalty. With regard to most of the statutory mitigators, it appears that all participants were inclined to give the defendant a break.

In contrast, death-qualified participants, when compared to Witt excludables, were less likely to believe that nonstatutory mitigators were valid reasons to give someone a life sentence. This may be due to the fact that most of the nonstatutory mitigators centered on character issues perceived to be within a person's control (e.g., 
alcoholism; past impairment by illegal drugs; use of psychotropic medications). It is plausible that venirepersons may have thought that the defendant assumed a certain risk factor when engaging in the aforementioned behaviors. In contrast, most of the statutory mitigators involved issues of mens rea, and, consequently, were not necessarily volitional in nature (e.g., age; unable to appreciate the criminality of their conduct or conform their conduct to the requirements of law; extreme duress or under the substantial domination of another person). Death-qualified participants may have viewed the nonstatutory mitigators as "excuses" as opposed to veritable explanations for a person's actions.

Surprisingly, none of the demographic characteristics were significantly related to either death qualification or participants' evaluations of aggravating and mitigating circumstances. However, men were significantly more likely to sentence the defendant to death. This apparent inconsistency may have several explanations.

Some may posit that a representative sample was not obtained. However, participants were comprised of 450 members of the venire from the Eleventh Judicial Circuit of the State of Florida and were demographically representative of Dade County. Therefore, this explanation appears unlikely. Another potential reason is that Dade County, in and of itself, is demographically unique and is, therefore, not representative of the United States as a whole. However, Moran and Comfort (1986) also utilized the venire from the Eleventh Judicial Circuit of the State of Florida and obtained results that supported earlier research with respect to demographic indices. Consequently, this explanation does not appear to suffice. Third, the aggravating and mitigating circumstances listed in Florida Statutes 921.141(5) and 921.141(6) could be atypical of the special circumstances found in other states that utilize capital punishment. However, 
an examination of the capital statutes of several states revealed that they are virtually identical to those found in Florida, which only serves to enhance the generalizibility of the present findings. A fourth possible explanation is simply due to the fact that attitudes toward capital punishment have changed and are no longer related to such things as gender or ethnic background. Much of the death qualification research was done over a decade ago; further research is necessary in order to isolate the cause behind this anomalous effect.

The results of this study have broad legal implications. The present findings both replicate and extend earlier research to demonstrate the salient effect that death qualification has on juries, and, consequently, due process.

Death qualification has been shown to systematically taint all stages of a capital trial: voir dire; the guilt phase; and the penalty phase. Haney (1984) demonstrated that the mere process of death qualification predisposes juries to the presumption of guilt on the part of the defendant. Other studies have shown that death qualification excludes certain demographic and attitudinal subgroups from capital jury service, which results in juries that are less representative, and, consequently, more biased (Hans, 1986; Moran \& Comfort, 1986). In addition, death-qualified jurors are more likely to be pro-prosecution, and, consequently, pro-conviction than their excludable counterparts (Cowan et al., 1984; Fitzgerald \& Ellsworth, 1984; Thompson et al., 1984).

The current study points to yet another biasing effect of death qualification. A death-qualified jury is significantly more likely to impose the death penalty than a jury comprised of excludables. This bias may arise out of the fact that death-qualified jurors are more receptive to aggravating, as opposed to mitigating circumstances. As a result, 
defendants in capital trials are subjected to juries that are oriented toward accepting aggravators and rejecting mitigators. Clearly, this effect can have grave legal implications.

So, what is the legal system to do? In Lockhart, the Court ruled that death qualification was not prejudicial in nature; however, the data indicate otherwise. Given the recent controversy surrounding a proposed moratorium on the death penalty, this issue has been brought into the forefront of American consciousness with a vengeance. Uneasiness about the ultimate punishment is to be expected. However, it is imperative that future research be conducted to examine the present finding that Witt results in the seating of differentially partial jurors. Should this effect be supported, it would be appropriate to conclude that Witt is fundamentally unfair.

The endorsement of death qualification in Lockhart may be settled law, but it is not settled fact. Although the state does have a legitimate interest in having capital jurors that are able and willing to impose both penalties, it appears that this guarantee is at the cost of capital defendants' right to due process (Luginbuhl \& Middendorf, 1988). This is a price too steep for any defendant to pay. 


\section{REFERENCES}

Bersoff, D. N. (1987). In the Supreme Court of the United States: Lockhart v. McCree. American Psychologist, 42(1), 59-68.

Cowan, C. L., Thompson, W. C., \& Ellsworth, P. C. (1984). The effects of death qualification on jurors' predisposition to convict and on the quality of deliberation. Law and Human Behavior, 8, 53-79.

Dillehay, R. C., \& Sandys, M. R. (1996). Life under Wainwright v. Witt: Juror dispositions and death qualification. Law and Human Behavior, 20(2), 147-165.

Festinger, L. (1957). A theory of cognitive dissonance. Stanford, CA: Stanford University Press.

Fitzgerald, R., \& Ellsworth, P. C. (1984). Due process vs. crime control: Death qualification and jury attitudes. Law and Human Behavior, 8, 31-51.

Furman v. Georgia, 408 U. S. 238 (1972).

Haney, C. (1984). On the selection of capital juries: The biasing effects of death qualification. Law and Human Behavior, 8, 121-132.

Haney, C. (1984). Examining death qualification: Further analysis of the process effect. Law and Human Behavior, 8, 133-151.

Haney, C., Hurtado, A., \& Vega, L. (1994). "Modern" death qualification: New data on its biasing effects. Law and Human Behavior, 18(6), 619-633.

Hans, V. P. (1986). Death by jury. In K. C. Haas \& J. A. Incardi (Eds.), Challenging capital punishment: Vol. 24. Legal and social science approaches (pp. 149175). Beverly Hills: Sage.

Lockett v. Ohio, 438 U. S. 586 (1978).

Lockhart v. McCree, 106 S. Ct. 1758 (1986).

Luginbuhl, J., \& Middendorf, K. (1988). Death penalty beliefs and jurors' responses to aggravating and mitigating circumstances in capital trials. Law and Human Behavior, 12(3), 263-281.

Moran, G., \& Comfort, J. C. (1986). Neither "tentative" nor "fragmentary:" Verdict preference of impaneled felony jurors as a function of attitude toward capital punishment. Journal of Applied Psychology, 71, 146-155. 
Neises, M. L., \& Dillehay, R. C. (1987). Death qualification and conviction proneness: Witt and Witherspoon compared. Behavioral Sciences and the Law, 5(4), 479494.

Robinson, R. J. (1993). What does "unwilling to impose the death penalty mean anyway? Another look at excludable jurors. Law and Human Behavior, 17(4), 471-477.

Thompson, W. C. (1989). Death qualification after Wainwright v. Witt and Lockhart v. McCree. Law and Human Behavior, 13(2), 185-215.

Thompson, W. C., Cowan, C. L., Ellsworth, P. C., \& Harrington, J. C. (1984). Death penalty attitudes and conviction proneness: The translation of attitudes into verdicts. Law and Human Behavior, 8, 95-113.

Tversky, A., \& Kahneman, D. (1974). Judgement under uncertainty: Heuristics and biases. Science, $185,1124-1131$.

Wainwright v. Witt, 105 S. Ct. 844 (1985).

Witherspoon v. Illinois, 391 U.S. 510 (1968).

Zeisel, H. (1968). Some data on juror attitudes toward capital punishment. (Monograph). University of Chicago Law School, Center for Studies in Criminal Justice. 
Table 1

Mean Evaluations of Aggravators as a Function of Death Qualification.

\begin{tabular}{lcc}
\hline Aggravator & Death-Qualified & Excludable \\
\hline HAC & 4.86 & 3.00 \\
Another Crime & 4.66 & 2.89 \\
Arrest/Escape & 4.63 & 2.87 \\
Gang & 4.58 & 3.06 \\
Elderly/Disabled & 4.91 & 3.31 \\
Financial Gain & 4.69 & 3.17 \\
CCP & 5.33 & 3.45 \\
Victim Under 12 & 3.78 & 2.51 \\
Victim Officer & 4.39 & 2.76 \\
Victim Public Official & 3.93 & 2.52 \\
Felony Probation & 3.60 & 2.73 \\
Disrupt/Hinder Laws & 4.61 & 3.33 \\
Previous Conviction & 3.73 & 2.71 \\
Great Risk to Many & 4.27 & 3.01 \\
\hline Note. All & & \\
\hline
\end{tabular}

Note. All means within rows are significantly different at the $\mathrm{p}<.001$ level. 
Table 2

Mean Evaluations of Nonstatutory Mitigators as a Function of Death Qualification.

\begin{tabular}{lcc}
\hline Nonstatutory Mitigator & Death-Qualified & Excludable \\
\hline Alcoholism & 2.64 & 3.72 \\
Illegal Drugs & 2.40 & 3.53 \\
Child Abuse & 2.67 & 3.61 \\
Military & 2.38 & 3.62 \\
Prescription Drugs & 3.53 & 4.42 \\
\hline
\end{tabular}

Note. All means within rows are significantly different at the $\mathrm{p}<.001$ level. 
Table 3

Mean Evaluations of Statutory Mitigators as a Function of Death Qualification.

\begin{tabular}{lcc}
\hline Mitigator & Death-Qualified & Excludable \\
\hline Mental/Emotional* & 3.52 & 4.21 \\
Teenager & 3.32 & 2.96 \\
Appreciate/Conform & 4.08 & 4.12 \\
Accomplice & 4.22 & 4.48 \\
Duress/Domination & 3.77 & 3.47 \\
No Prior History & 3.46 & 3.34 \\
Victim Participation & 3.66 & 3.55 \\
\hline
\end{tabular}

$* \mathrm{p}<.001$ 
APPENDIX A 
1. The crime for which (defendant) is to be sentenced was committed while [he] [she] had been previously convicted of a felony and [was under sentence of imprisonment] [or] [was placed on community control] [or] [was on felony probation].

2. The defendant has been previously convicted of another capital offense or of a felony involving the [use] [threat] of violence to some person;

a. The crime of (previous crime) is a capital felony.

b. The crime of (previous crime) is a felony involving the [use] [threat] of violence to another person.

3. The defendant, in committing the crime for which [he] [she] is to be sentenced, knowingly created a great risk of death to many persons.

4. The crime for which the defendant is to be sentenced was committed while [he] [she] was

[engaged]

[an accomplice]

in

[the commission of]

[an attempt to commit]

[flight after committing or attempting to commit]

the crime of

[robbery]

[sexual battery] 
[aggravated child abuse]

[abuse of an elderly person or disabled adult resulting in great bodily harm, permanent disability, or permanent disfigurement]

[arson]

[burglary]

[kidnapping]

[aircraft piracy]

[the unlawful throwing, placing or discharging of a destructive device or a bomb];

5. The crime for which the defendant is to be sentenced was committed for the purpose of avoiding or preventing a lawful arrest or effecting an escape from custody.

6. The crime for which the defendant is to be sentenced was committed for financial gain.

7. The crime for which the defendant is to be sentenced was committed to disrupt or hinder the lawful exercise of any governmental function or the enforcement of laws.

8. The crime for which the defendant is to be sentenced was especially heinous, atrocious, or cruel.

9. The crime for which the defendant is to be sentenced was committed in a cold and calculated and premeditated manner, and without any pretense of moral or legal justification.

10. The victim of the crime for which the defendant is to be sentenced was a law enforcement offer engaged in the performance of the officer's official duties. 
11. The victim of the crime for which the defendant is to be sentenced was an elected or appointed public official engaged in the performance of [his] [her] official duties.

12. The victim of the capital felony was a person less than 12 years of age.

13. The victim of the capital felony was particularly vulnerable due to advanced age or disability; or because the defendant stood in a position of familial or custodial authority over the victim.

14. The capital felony was committed by a criminal street gang member. 
Florida Statute 921.141(6): Mitigating Circumstances

1. (Defendant) has no significant history of prior criminal activity.

2. The crime for which the defendant is to be sentenced was committed while [he] [she] was under the influence of extreme mental or emotional disturbance.

3. The victim was a participant in the defendant's conduct or consented to the act.

4. The defendant was an accomplice in the offense for which [he] [she] is to be sentenced but the offense was committed by another person and the defendant's participation was relatively minor.

5. The defendant acted under extreme duress or under the substantial domination of another person.

6. The capacity of the defendant to appreciate the criminality of [his] [her] conduct or to conform [his] [her] conduct to the requirements of law was substantially impaired.

7. The age of the defendant at the time of the crime.

8. Any of the following circumstances that would mitigate against the opposition of the death penalty:

a. Any [other] aspect of the defendant's character, record, or background.

b. Any other circumstance of the offense. 
APPENDIX B 


\section{JUROR SURVEY}

This survey is a scientific project designed to increase understanding of how real jurors reach their verdicts. It is strictly voluntary and anonymous. You can be assured that all responses will be treated with the utmost confidence.

Please read the attached case very carefully. Take your time. Then, answer all questions to the best of your ability. There are no right or wrong answers. We are looking for your truthful answers based solely upon your personal experiences, knowledge, and opinions.

If you have any questions about the project, I encourage you to call me at (305)348-2880. If you would like to receive a copy of the final report, please call the number above and leave your name and address.

Thank you for taking part in this study. You will enable us to guide judges and attorneys in ways to ensure fair and impartial juries in criminal cases.

Sincerely,

Brooke M. Butler

Florida International University

Department of Psychology 
1. Which statement do you agree with most?

1. The death penalty is never an appropriate punishment for the crime of first-degree murder.

2. In principle, I am opposed to the death penalty, but I would consider it under certain circumstances as an appropriate form of punishment for first-degree murder.

3. In principle, I favor the death penalty, but I would not consider it under all circumstances in cases of first-degree murder.

4. The only appropriate punishment for the crime of first-degree murder is the death penalty.

2. Do your beliefs about the death penalty prevent or substantially impair you from being able to give consideration to both penalties (either life in prison without the possibility of parole or the death penalty)?

1. No

2. Yes 
Criminal Case Summary: FL v. Andrew Jones 


\section{Capital cases have TWO parts: (1) the guilt phase and (2) the penalty phase.}

\section{Summary of Testimony Presented During the Guilt Phase}

At 6:00 p.m. on August 1, 1999, the Quick Stop gas station in Miami, Florida was robbed. Three eyewitnesses testified that the perpetrator entered the gas station, pulled a handgun from his pocket, pointed it at the cashier, and demanded all the money in the cash register. When the cashier turned to open the cash register, the perpetrator shouted, "Hurry up!" When the cashier fumbled with the cash register, the perpetrator fired one shot, knocking the cashier to the ground and killing him instantly. The perpetrator then opened the cash register, stuffed the money (amounting to $\$ 300$ ) into his pockets, and fled the scene. One of the three eyewitnesses called 911 from the pay phone outside the gas station. Both the ambulance and police arrived within five minutes. Emergency personnel pronounced the victim dead at the scene and the police began to search for the suspect in the neighborhood surrounding the gas station.

At approximately 6:45 p.m., the police spotted a man matching the description of the suspect walking within a half of a mile of the Quick Stop. When questioned, the man told the officers that his name was Andrew Jones and that he was walking home from work. He told the police officers that he was employed as a construction worker at a site about a half mile away from his home. His home was about a mile away from the gas station. Mr. Jones said that he had left work at 6:30 p.m. and began his walk home. When the police checked out his story, they found that Mr. Jones did, indeed, live where he said he did. Mr. Jones also worked at the construction site where he had claimed to work. However, employees at the site said that Mr. Jones was last seen working at 5:00 p.m., as opposed to $6: 30$ p.m.

The police searched Mr. Jones and found $\$ 300$ in his pockets. Andrew Jones was arrested and taken to the police station and placed in a line up. All three eyewitnesses confidently identified Mr. Jones as the suspect. A crime scene analysis revealed that Mr. Jones' fingerprints were found on the cash register. The gun was never found.

Based on the testimony of the eyewitnesses, the police, Mr. Jones' coworkers, the medical examiner, and the crime scene expert, the defendant was tried and convicted of one count of first-degree murder.

Andrew Jones continues to deny his involvement in the murder. He claims that the police planted the evidence against him. He also says that the eyewitnesses were pressured into identifying him and that they are mistaken. 


\section{Summary of Testimony Presented During the Penalty Phase}

\section{The Prosecution:}

The prosecution has offered evidence for you to consider when deciding the penalty for Andrew Jones. All of the issues the prosecutor presents are official "aggravating circumstances" in Florida. An aggravator is a legal reason to favor the death penalty over the sentence of life in prison without the possibility of parole.

The prosecutor noted that the charge of first-degree murder is a capital felony and should be punishable by death. In addition, the murder occurred during the commission of another felony: armed robbery. The prosecution also said that Mr. Jones not only has a prior history of violence, but that the murder was committed while he was on probation. (In 1994, Andrew Jones had been tried and convicted of assaulting a person with a deadly weapon during a barroom brawl. He served three years in prison and was sentenced to five years probation.)

The State also noted that the clerk, a family man with a wife and three children, was murdered for $\$ 300$. During the penalty phase, the prosecutor said, "Although it is difficult to put monetary value on human life, I think we all would agree that $\$ 300$ is grossly cheap."

All three eyewitnesses said that Mr. Jones seemed to act "in control," "did not seem nervous or scared," and "acted with almost military precision." They testified that they didn't understand why the cashier was shot, since he offered no resistance. One eyewitness said that after the cashier was shot, "There was a look of sheer hatred on Andrew Jones' face... his eyes were black...vacant. He knew we had seen him do this, but he didn't care."

Due to the reasons mentioned above, the prosecution feels that the aggravating circumstances outweigh the mitigating circumstances and, therefore, the appropriate sentence would be the death penalty.

\section{The Defense:}

The defense has offered evidence for you to consider when deciding the penalty for Andrew Jones. All of the things the defense attorney is presenting are "mitigating circumstances." A mitigator is a reason to consider life in prison without the possibility of parole as opposed to the death penalty.

The defense attorney argues that Mr. Jones was a brother, father, and friend. His mother testified that Andrew did not have an easy childhood. His father physically battered her and her three children. Andrew Jones' mother said that she divorced his father after she 
caught him trying to molest one of their daughters. One of Mr. Jones' two sisters said, “ Andy always tried to protect my mom, my sister, and me from Dad's wrath. Dad was so big, and Andy was so little...but he tried. Unfortunately, Andy only got beaten more."

Although he had proudly served in the Gulf War, he came back to find his life in shambles. His wife had left him, taking his newborn son with her. His friends said Andrew was a kind person, "....someone that would do anything for anyone." They said that his life was never the same after the woman he called "the love of his life... his soul mate" filed for divorce.

To ease his pain, Andrew Jones turned to alcohol, and, later, marijuana and cocaine. He lost his job due to his alcoholism and drug use and went on welfare for about a year. It was during this time that he was tried and convicted of assault with a deadly weapon during a barroom fight.

Determined to turn his life around, he took correspondence classes when he was in prison and, upon release, was hired as a construction worker. He stopped using alcohol and drugs. He started attending Alcoholics Anonymous (AA) meetings regularly. He began seeing a psychiatrist, who prescribed Luvox and Trazadone for Mr. Jones' depression. The psychiatrist testified that these medications are not for everyone. They can have grave side effects, such as erratic behavior and mood changes, especially when used with alcohol or other drugs. However, Andrew Jones seemed to respond well to the medication and his depression seemed to be lifting.

In one month before the murder, Mr. Jones life took a turn for the worse. He learned that his ex-wife was in town. He contacted her to arrange a visit with his son. She refused. Andrew became distraught and started drinking and using drugs again while he was on the antidepressants his doctor had prescribed. He would show up for work sporadically, and his boss told him that he was in danger of being fired.

For the reasons mentioned above, the defense feels that mitigating circumstances outweigh aggravating circumstances and, therefore, the appropriate sentence would be life in prison without the possibility of parole.

You may consider anything in mitigation. You may also give both aggravators and mitigators whatever weight seems appropriate to you. The ultimate decision as to the balance of the aggravating and mitigating circumstances is entirely up to you. 
These items concern your OPINION as to the appropriateness of either life in prison without the possibility of parole or the death penalty in certain circumstances. Please indicate, by circling a number, the extent to which you agree with that item.

1. If a person commits a crime that is especially heinous, atrocious, or cruel, then they should receive the death penalty. (A)

$\begin{array}{llllllll}\text { Strongly Disagree } & 1 & 2 & 3 & 4 & 5 & 6 & \text { Strongly Agree }\end{array}$

2. If a person has a history of alcoholism, then they should not receive the death penalty. (NM)

$\begin{array}{lllllllll}\text { Strongly Disagree } & 1 & 2 & 3 & 4 & 5 & 6 & \text { Strongly Agree }\end{array}$

3. If there is testimony by a mental health expert that the defendant was suffering from an extreme mental or emotional disturbance, the defendant should not get the death penalty. (SM)

$\begin{array}{llllllll}\text { Strongly Disagree } & 1 & 2 & 3 & 4 & 5 & 6 & \text { Strongly Agree }\end{array}$

4. If a person committed a murder while engaged in the commission of a robbery (or any other crime), then he should receive the death penalty. (A)

$\begin{array}{llllllll}\text { Strongly Disagree } & 1 & 2 & 3 & 4 & 5 & 6 & \text { Strongly Agree }\end{array}$

5. It would be unreasonable to give a person the death penalty if he has been impaired by illegal drugs in the past. (NM)

$\begin{array}{llllllll}\text { Strongly Disagree } & 1 & 2 & 3 & 4 & 5 & 6 & \text { Strongly Agree }\end{array}$

6. A person who commits murder for the purpose of avoiding or preventing a lawful arrest or effecting an escape from custody should receive the death penalty. (A)

$\begin{array}{lllllllll}\text { Strongly Disagree } & 1 & 2 & 3 & 4 & 5 & 6 & \text { Strongly Agree }\end{array}$

7. A member of a gang who commits murder should receive the death penalty. (A)

$\begin{array}{llllllll}\text { Strongly Disagree } & 1 & 2 & 3 & 4 & 5 & 6 & \text { Strongly Agree }\end{array}$

8. A person who murders an elderly person or disabled person should receive the death penalty. (A)

$\begin{array}{llllllll}\text { Strongly Disagree } & 1 & 2 & 3 & 4 & 5 & 6 & \text { Strongly Agree }\end{array}$

Note. $\mathrm{A}=$ Aggravator; $\mathrm{SM}=$ Statutory Mitigator; $\mathrm{NM}=$ Nonstatutory Mitigator. These abbreviations did not appear on participants' protocol. 
9. Physical abuse as a child is a reason not to receive the death penalty. (NM) $\begin{array}{llllllll}\text { Strongly Disagree } & 1 & 2 & 3 & 4 & 5 & 6 & \text { Strongly Agree }\end{array}$

10. A person who murders someone for financial gain should receive the death penalty. (A)

$\begin{array}{llllllll}\text { Strongly Disagree } & 1 & 2 & 3 & 4 & 5 & 6 & \text { Strongly Agree }\end{array}$

11. If a person commits a murder in a cold, calculated, and premeditated manner, without any pretense of moral or legal justification, they should receive the death penalty. (A)

$\begin{array}{lllllllll}\text { Strongly Disagree } & 1 & 2 & 3 & 4 & 5 & 6 & \text { Strongly Agree }\end{array}$

12. A person who commits a crime as a teenager should receive life in prison without the possibility of parole. (SM)

$\begin{array}{llllllll}\text { Strongly Disagree } & 1 & 2 & 3 & 4 & 5 & 6 & \text { Strongly Agree }\end{array}$

13. If the victim of a crime was a person less than 12 years of age, then the defendant should receive the death penalty. (A)

$\begin{array}{llllllll}\text { Strongly Disagree } & 1 & 2 & 3 & 4 & 5 & 6 & \text { Strongly Agree }\end{array}$

14. A person who is unable to appreciate the criminality of his conduct or is unable to conform his conduct to the requirements of law (e.g., suffering from a mental illness) should not receive the death penalty. (SM)

$\begin{array}{llllllll}\text { Strongly Disagree } & 1 & 2 & 3 & 4 & 5 & 6 & \text { Strongly Agree }\end{array}$

15. If the victim of a crime was a law enforcement officer engaged in the performance of the officer's actual duties, then the defendant should receive the death penalty. (A)

$\begin{array}{llllllll}\text { Strongly Disagree } & 1 & 2 & 3 & 4 & 5 & 6 & \text { Strongly Agree }\end{array}$

16. If a person commits a crime against an elected or appointed public official (e.g., Joe Carollo) engaged in the commission of his official duties, then they should receive the death penalty. (A)

$\begin{array}{llllllll}\text { Strongly Disagree } & 1 & 2 & 3 & 4 & 5 & 6 & \text { Strongly Agree }\end{array}$ 
17. If a person was an accomplice in a crime, but their participation was relatively minor, they should not receive the death penalty. (SM)

$\begin{array}{lllllllll}\text { Strongly Disagree } & 1 & 2 & 3 & 4 & 5 & 6 & \text { Strongly Agree }\end{array}$

18. A person who committed an offense while under extreme duress or under the substantial domination of another person (e.g., the Patty Hearst case) should receive life in prison without the possibility of parole. (SM)

$\begin{array}{llllllll}\text { Strongly Disagree } & 1 & 2 & 3 & 4 & 5 & 6 & \text { Strongly Agree }\end{array}$

19. If a person commits another crime while he was on felony probation, then he should receive the death penalty. (A)

$\begin{array}{llllllll}\text { Strongly Disagree } & 1 & 2 & 3 & 4 & 5 & 6 & \text { Strongly Agree }\end{array}$

20. If a person commits a crime to disrupt or hinder the lawful exercise of any governmental function or the enforcement of laws (e.g., the Oklahoma City bombing case), then they should receive the death penalty. (A)

$\begin{array}{lllllllll}\text { Strongly Disagree } & 1 & 2 & 3 & 4 & 5 & 6 & \text { Strongly Agree }\end{array}$

21. A person who had served in the military before the crime was committed should not receive the death penalty. (NM)

$\begin{array}{lllllllll}\text { Strongly Disagree } & 1 & 2 & 3 & 4 & 5 & 6 & \text { Strongly Agree }\end{array}$

22. A person was taking prescription drugs that have the potential to alter their psychological state when the murder was committed should not receive the death penalty. (NM)

$\begin{array}{lllllllll}\text { Strongly Disagree } & 1 & 2 & 3 & 4 & 5 & 6 & \text { Strongly Agree }\end{array}$

23. If a person had been previously convicted of a felony involving the use of violence, they should receive the death penalty. (A)

$\begin{array}{lllllllll}\text { Strongly Disagree } & 1 & 2 & 3 & 4 & 5 & 6 & \text { Strongly Agree }\end{array}$

24. If a person, upon committing a crime, knowingly created a great risk of death to many persons, then he should receive the death penalty. (A)

$\begin{array}{lllllllll}\text { Strongly Disagree } & 1 & 2 & 3 & 4 & 5 & 6 & \text { Strongly Agree }\end{array}$

25. A person who has no significant history of prior criminal activity should receive the sentence of life in prison without the possibility of parole. (SM) 
$\begin{array}{lllllllll}\text { Strongly Disagree } & 1 & 2 & 3 & 4 & 5 & 6 & \text { Strongly Agree }\end{array}$

26. A life sentence is appropriate if the victim participated in or consented to the act in any way (e.g., a person inadvertently dies after they agree to be suffocated to the point of unconsciousness during a sexual act). (SM)

$\begin{array}{lllllllll}\text { Strongly Disagree } & 1 & 2 & 3 & 4 & 5 & 6 & \text { Strongly Agree }\end{array}$ 


\section{Sentence}

You have read the summaries of the guilt and penalty phases. You have also read the judge's instructions. It is now your responsibility to determine the punishment of Andrew Jones. Please remember: If the aggravators outweigh the mitigators, you must impose the death penalty. If the mitigators outweigh the aggravators, you must sentence him to life.

For the crime of first-degree murder, Andrew Jones should be sentenced to

1. death.

2. life in prison without the possibility of parole. 


\section{Please answer the following demographic questions.}

1. Gender:

1. Female

2. Male

2. Age:

1. $\quad 18-24$

2. $25-34$

3. $35-44$

4. $\quad 45-54$

$5 . \quad 55-64$

6. $65+$

3. Ethnic Background:

1. White/Non-Hispanic

2. White/Hispanic

3. Black/Hispanic

4. Black

5. Other

4. Educational level

1. No high school

2. Some high school

3. High school diploma

4. Some college/Jr. college

5. College degree

6. Post-graduate/Professional degree

5. Occupation:

1. Homemaker

2. Professional/technical

3. Salesperson

4. Manager

5. Clerical/Secretarial

6. Craftsperson/Laborer

7. Service worker

8. Teacher

9. Student

10. Self-employed (small business)

11. Not working now/Unemployed

12. Retired 
6. Have you ever served on a civil or a criminal jury before?

1. No

2. Yes

7. If you answered "yes" to Question 6, which one?

1. Civil

2. Criminal

8. Independent of your party affiliation, how would you describe your current political views?

1. Conservative

2. Slightly conservative

3. Slightly liberal

4. Liberal

9. Please indicate your annual family income:

1. Less than 20,000

2. 20,000 to 30,000

3. 30,000 to 45,000

4. $\quad 45,000$ to 60,000

$5 \quad 60,000$ to 75,000

6. $75,000+$ 
BROOKE M. BUTLER
August 1, 1973
Born, Atlanta, Georgia
1994
B.A., Psychology, summa cum laude
University of North Florida
Jacksonville, Florida
1995-1996
Research Assistant
University of North Florida
Jacksonville, Florida
1996-1997
Teaching Assistant
University of North Florida
Jacksonville, Florida
1997
M.A., Psychology
University of North Florida
Jacksonville, Florida
1997-2000
Doctoral Candidate in Psychology
Florida International University
Miami, Florida
$1997-2000$
Instructor
Florida International University
Miami, Florida

\section{PRESENTATIONS}

Butler, B. (March, 2000). Information integration in attorney decision making. Poster presented at the biennial meeting of the American-Psychology Law Society, New Orleans, LA.

Butler, B. \& Foley, L. (March, 1998). Impact of victim demeanor and occupational dress on juror decisions. Poster presented at the biennial meeting of the AmericanPsychology Law Society, Redondo Beach, CA.

Butler, B. \& Foley, L. (April, 1997). Perceptions of sexual harassment: Influence of victim gender and attractiveness. Poster presented at the annual meeting of the Southeastern Psychological Association, Atlanta, GA. 